\title{
Energetic efficiency of protein and body fat retention in crossbred Bos indicus and Bos Taurus $\times$ Bos indicus raised under tropical conditions
}

\section{Douglas Sampaio Henrique ${ }^{1^{*}}$, Augusto César de Queiroz ${ }^{2}$, Ricardo Augusto Mendonça Vieira $^{3}$, Mosar Faria Botelho ${ }^{4}$}

\footnotetext{
1 Pós-doutorando do Departamento de Zootecnia da Universidade Federal de Viçosa.

2 Universidade Federal de Viçosa.

${ }^{3}$ Universidade Estadual do Norte Fluminense Darcy Ribeiro.

4 Universidade Tecnológica Federal do Paraná.
}

ABSTRACT - The efficiency of fat and protein retention by Bos indicus and its cross-breds was estimated from data obtained in the literature to verify possible differences between these animals and Bos taurus. After estimating the efficiencies, a correction factor was used to discount the metabolizable energy fraction that was spent in the maintenance and support metabolism processes. The efficiencies were then estimated again, assuming that all the remaining energy would correspond to the metabolizable energy available for body mass retention. The correction value used was considered satisfactory to discount energetic losses for maintenance and support. The efficiency values of partial body fat and protein retention in Bos indicus and its cross-bred were very similar to values reported by other authors who researched Bos taurus exclusively.

Key Words: beef-cattle, bioenergetics, mathematical models

\section{Eficiência energética de retenção de proteína e gordura corporal em zebuínos e mestiços Europeu × Zebu mantidos em clima tropical}

\footnotetext{
RESUMO - A eficiência com que animais zebuínos e seus cruzamentos transformam a energia metabolizável consumida em gordura e proteína corporal foi estimada a partir de informações obtidas na literatura no intuito de verificar se existem diferenças entre esses animais e os de raças europeias. Após a estimativa das eficiências, usou-se uma correção para descontar a porção da energia metabolizável gasta na manutenção da massa corporal e no metabolismo de suporte. Posteriormente à aplicação da correção, as eficiências foram estimadas novamente, partindo-se do pressuposto de que o montante de energia restante corresponderia à energia metabolizável utilizada para acúmulo de massa corporal. O valor de correção utilizado foi considerado suficiente para descontar as perdas energéticas para mantença e suporte. Os valores de eficiência de retenção parcial de gordura e proteína corporal em animais zebuínos e mestiços Europeu $\times$ Zebu são muito próximos dos encontrados por outros autores em pesquisas com animais exclusivamente europeus.
}

Palavras-chave: bioenergética, bovinos de corte, modelos matemáticos

\section{Introduction}

The proportion of protein and fat in the animal body varies during growth. Under ad libitum intake conditions, fat concentration in the body tends to increase while the protein proportion decreases. Other factors such as genetic group, gender and physiological status influence the body composition (NRC, 1996). These differences in body composition affect the efficiency of food energy utilization by the animal. The protein turnover in tissues spends energy and consequently reduces the efficiency of protein retention in the animal body (Owes et al., 1995).

Nevertheless, most systems used for modeling cattle nutrient requirements do not account for the effect of body composition in the energetic efficiency for growth, but only the energy concentration of the $\operatorname{diet}$ (Geay, 1984).

Williams \& Jenkins (2003a) proposed a complex mathematical model to estimate the body mass gain from the metabolizable energy intake, in which body mass gain is a function of the food energy and body composition. In this system, the energetic efficiency of fat and protein

Received August 18, 2008 and accepted March 5, 2009. 
retention are $75 \%$ and $20 \%$ respectively, as estimated by Geay (1984) using a large data bank. However, the data collected by Geay (1984) are from Bos taurus animals raised under temperate climate conditions.

The NRC (1996) uses correction factors to estimate the maintenance energy requirements for Bos indicus, Bos taurus and crossbred cattle, justifying this procedure with the argumentation that Bos indicus cattle have lower maintenance requirements than Bos taurus because their protein turnover is lower than the latter, then crossbred cattle requirements would be intermediate.

In this paper, the efficiency of protein and fat retention were estimated using data from Bos indicus and Bos indicus $\times$ Bos taurus crossbred cattle raised under tropical climate conditions.

\section{Material and Methods}

Data used to estimate the use efficiency of feed energy for protein and fat retention were obtained from 267 individual data of metabolizable energy intake (MEI, $\mathrm{kcal} / \mathrm{kg}^{0.75}$ day), retained energy (RE, $\mathrm{kcal} / \mathrm{kg}^{0.75}$ day) and body mass gain (BMG, $\mathrm{kg}$ /day) obtained from research carried out at the Universidade Federal de Viçosa (Freitas, 1995; Paulino, 2002; Salvador, 1980; Ferreira, 1997; Freitas, 2004; Teixeira, 1984) and at experiments conducted at the Instituto de Zootecnia de Nova Odessa, São Paulo (Tedeschi, 2001) (Table 1).

Information was used to estimate daily fat and protein retention by the following equations, deduced by Williams \& Jenkins (2003b):

$\mathrm{dFAT}=(\mathrm{RE}-1,39 \cdot \mathrm{BMG}) / 8.11$

$\mathrm{dPRO}=(\mathrm{BMG}-\mathrm{dFAT}) \cdot 0.243$

where $\mathrm{dFAT}$ and $\mathrm{dPRO}=$ daily retention $(\mathrm{kg} /$ day) of body fat and protein, respectively; $\mathrm{BMG}=$ body mass gain ( $\mathrm{kg} /$ day); and $\mathrm{RE}=$ retained energy $\left(\mathrm{kcal} / \mathrm{kg}^{0.75} \mathrm{day}\right)$.

The observed metabolizable energy intake values and the calculated dFAT and dPRO values for each animal were used in multiple regression analysis, to determine how much of the metabolizable energy intake (MEI) was used for maintenance and for protein and fat retention, as shown in the equation below (Williams \& Jenkins, 2003b):

$\mathrm{MEI}=\beta_{0}+\beta_{1} \mathrm{dPRO}+\beta_{2} \mathrm{dFAT}$

In this equation, metabolizable energy intake was expressed in $\mathrm{Mcal} / \mathrm{kg}^{0.75}$ day and the variables $\mathrm{dPRO}$ and dFAT were also corrected according to metabolic size $\left(\mathrm{kg} / \mathrm{kg}^{0.75}\right.$ day); the intercept $\left(\beta_{0}\right)$ was interpreted as an estimate of the energy used for maintenance (Mcal $/ \mathrm{kg}^{0.75}$ day) and the partial coefficients of the $\beta_{1}$ and $\beta_{2}$ regression represented the amount of metabolizable energy (Mcal/ $\mathrm{kg}^{0.75} /$ day) needed for one $\mathrm{kg}$ of protein and fat deposition, respectively. Coefficients obtained from this regression analysis were used to calculate the retention efficiencies of protein $\left(\mathrm{k}_{\mathrm{p}}\right)$ and fat $\left(\mathrm{k}_{\mathrm{f}}\right)$ :

$\mathrm{k}_{\mathrm{p}}=5.7 / \hat{\beta}_{1}$

$\mathrm{k}_{\mathrm{f}}=9.5 / \hat{\beta}_{2}$

in which 5.7 and 9.5 represented the energy concentrations (Mcal) in one kilogram of dry matter of protein and fat, respectively.

\section{Results and Discussion}

The increase in energy intake caused a greater increase in fat than in protein retention (Figure 1), because the excess energy consumed was transformed into fat even if the source fed was of protein origin. Once the requirement of the animal was supplied, the excess of aminoacids (monomeric constituents of proteins) was deaminated and its carbon structures could be used by the animal as energy source or stored mainly as fat (Stryer, 1996).

The increase in protein proportion in body mass gain ( $\mathrm{dPRO} / \mathrm{BMG}$ ) caused a reduction at the ratio between retained energy and metabolizable energy intake (RE/MEI) (Figure 2). This ratio may be considered a measure of gross efficiency of energy retention (Brody, 1945). As protein tissues have higher metabolic activity (they spend more energy) than the fat tissue, it would be consistent to infer

Table 1 - Data set description

\begin{tabular}{lcccc}
\hline Genetic group & $\mathrm{n}$ & Metabolizable energy intakekcal/kg0.75 & Gender & Reference \\
\hline Holstein $\times$ Zebu & 34 & $77-250$ & Steer & Salvador $(1980)$ \\
Holstein $\times$ Zebu & 47 & $129-292$ & Steer & Teixeira (1984) \\
Nellore; Holstein $\times$ Nellore; & 22 & $100-280$ & Bull & Freitas $(1995)$ \\
Fleckvieh $\times$ Angus $\times$ Nellore; & & & Bull & Ferreira $(1997)$ \\
Nellore $\times$ Simmental & 24 & $231-342$ & Steer and Bull & Tedeschi (2001) \\
Nellore & 77 & $136-221$ & Steer & Paulino (2002) \\
Nellore & 15 & $153-307$ & Bull & Freitas (2004) \\
Nellore $\times$ Simental; Nellore $\times$ Angus; & 48 & $136-364$ & & \\
Nellore $\times$ Brown Swiss; Nellore & & & & \\
\hline
\end{tabular}




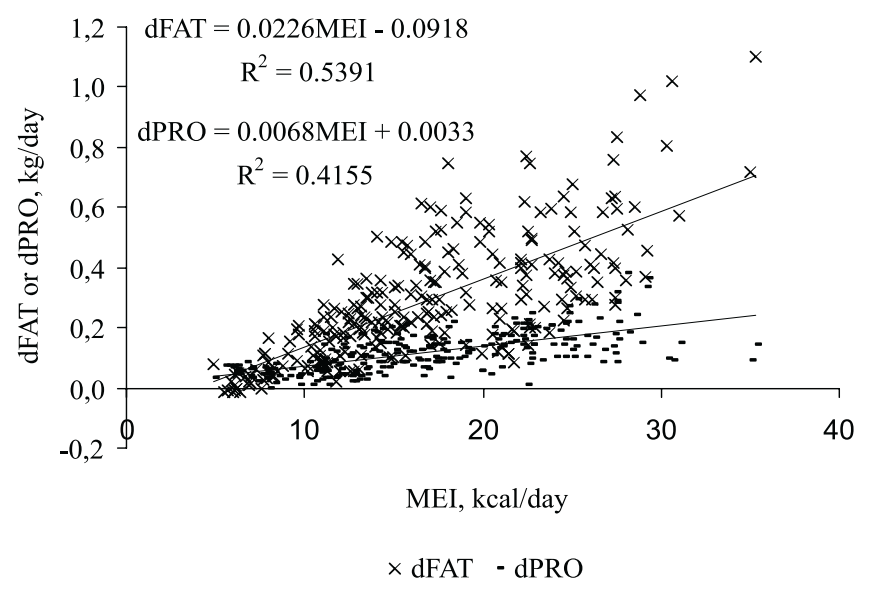

Figure 1 - Relation between metabolizable energy intake (MEI) and daily retention of fat (dFAT) and protein (dPRO).

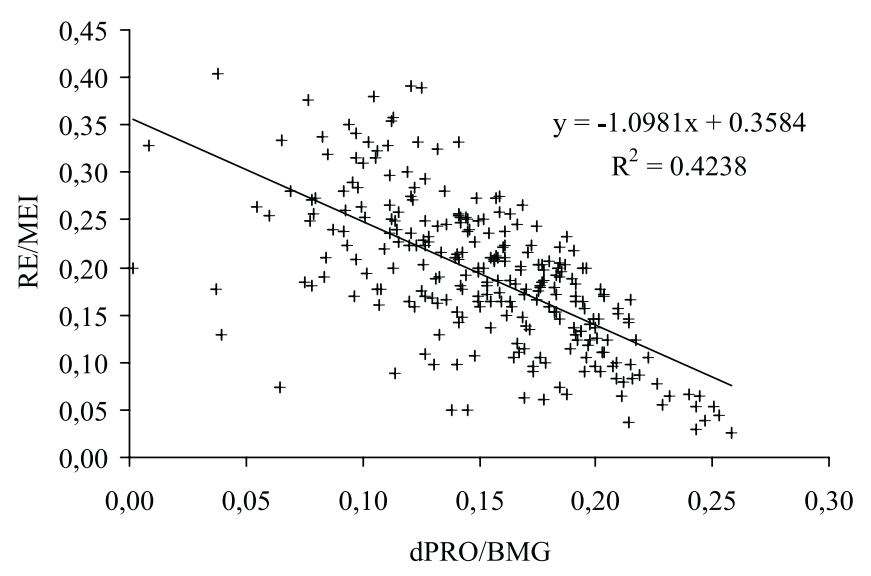

Figure 2 - Relation between protein proportion of body mass gain (dPRO/BMG) and gross efficiency of retention of metabolizable energy consumed (RE/MEI).

that the gross efficiency decreases as the protein proportion of body mass gain increases.

Seven data from the animals that lost their body mass were excluded from the data set used to generate the graph.

The result of the multiple regression of metabolizable energy intake compared to daily retention of protein (dPRO) and fat (dFAT) was:

$\mathrm{MEI}=0.11+34.02 \cdot \mathrm{dPRO}+14.35 \cdot \mathrm{dFAT}$

The $\mathrm{k}_{\mathrm{p}}$ and $\mathrm{k}_{\mathrm{f}}$ values calculated from the $\hat{\beta}_{1}$ and $\hat{\beta}_{2}$ estimates were 0.17 and 0.66 , respectively, and were lower than 0.20 for $\mathrm{k}_{\mathrm{p}}$ and 0.75 for $\mathrm{k}_{\mathrm{f}}$ found by Geay (1984). However, according to Williams \& Jenkins (2003b), these estimates may be underestimated, because the amount of energy used to supply the requirements of the maintenance and support metabolism $\left(0.11 \mathrm{Mcal} / \mathrm{kg}^{0.75}\right.$ day $)$ is low for animals consuming large amounts of metabolizable energy.
It means that part of the energy supposed to be spent exclusively on body retention may have been used by the support metabolism too.

Seven data from animals that lost their body mass were excluded from the data set used to generate the graph.

In the model developed by Williams \& Jenkins (2003a), maintenance $\left(\mathrm{ME}_{\mathrm{m}}\right)$ was considered constant per kilogram of body mass, regardless of current weight, intake level or animal age. This concept is based on experimental results conducted by Taylor et al. (1981) which showed a constant ratio between body mass and feed intake in Ayrshire cattle with body weight varying from 25 to $100 \%$ of the weight normally presented by this genetic group at maturity. These authors reported metabolizable energy intakes of 31.2 to $35.6 \mathrm{kcal} / \mathrm{kg}$ body mass in animals kept at constant weight for long periods of time, which indicated that all the energy consumed in this period was transformed to heat, that is, it was used for maintenance. Therefore, maintenance in proportion to live weight does not vary with age, body mass or level of consumption (previous or current) in animals kept in energetic equilibrium for long periods. According to Williams \& Jenkins (2003a), the variation in these cases is caused by the elevation of the support metabolism, which is positively related to feed intake and negatively to animal agel. In the old nutrient requirement systems, part of the support metabolism was added to the heat increase in production (increase of heat production in the animal due to molecular synthesis processes) and part to the maintenance heat increase (increase in body heat production due to the processes of nutrient digestion, absorption and assimilation and excreta formation). In the Williams \& Jenkins (2003a) model, the heat increase from the support metabolism is treated apart from the other two processes (maintenance and production).

Turner \& Taylor (1983) observed the effect of nutritional level prior to the experimental period during the time needed for animal metabolism stabilization. According to Webster (1978) cited by Turner \& Taylor (1983) and by Keele et al. (1992), beef cattle need to be kept at a fixed intake level for 3 to 4 weeks to stabilize the energetic metabolism. However, Turner \& Taylor (1983) demonstrated that in 28 days the animal metabolism presented a delay of $2 / 3$ (more or less, depending on whether the present intake level was higher or lower than the previous) in relation to the metabolism they would present if they were totally adapted to a certain intake level. Williams \& Jenkins (2003a) suggested that this delay of the metabolic equilibrium occurs also due to the support metabolism, since the metabolizable energy requirement for maintenance per kilogram body weight is considered constant at every intake level. 
The time for a fraction "q" of total response to be reached is, according to Turner \& Taylor (1983):

$\mathrm{t}_{\mathrm{q}}=[-\ln (1-\mathrm{q}) \tau]$

where $\tau=$ latency constant of first order; and $t_{q}=$ time, in days, for the animal to reach determined fraction q of heat production with totally stabilized metabolism. Considering equal to 28 days (a medium value suggested by the authors), the animal would need more than 100 days to stabilize its metabolism. Rearranging the equation (7), it is possible to calculate which fraction $q$ of the metabolism in equilibrium is reached at day $t$ :

$\mathrm{q}=1-\exp \left(-\mathrm{t}_{\mathrm{q}} / \tau\right)$

Therefore, in four weeks q would be equal to 0.63 , in 100 days $\mathrm{q}=0.97$ and in 129 days $\mathrm{q}=0.99$ (Figure 3 ).

In a hypothetical situation, based in the previous model, animal 1 was fed at the maintenance level and animal 2 at a level two times superior to the maintenance, during enough time for the stabilization of their metabolisms (Figure 4). Following that, the level fed to these animals was exchanged, which means that animal 1 started to receive double its maintenance requirements and animal 2 only enough for maintenance. Heat production at the maintenance level was considered $112 \mathrm{kcal}$ and at the other level $173 \mathrm{kcal}$. Heat production of animals 1 and 2 at 28 days would be 151 and $134 \mathrm{kcal}$, respectively, which indicated that this period was not enough for the metabolism to stabilize at the new nutritional level. Nevertheless, at 100 days the heat produced by animal 1 was $171 \mathrm{kcal}$ and by animal 2, $113 \mathrm{kcal}$, that was close enough to the values detected when the metabolism was stabilized.

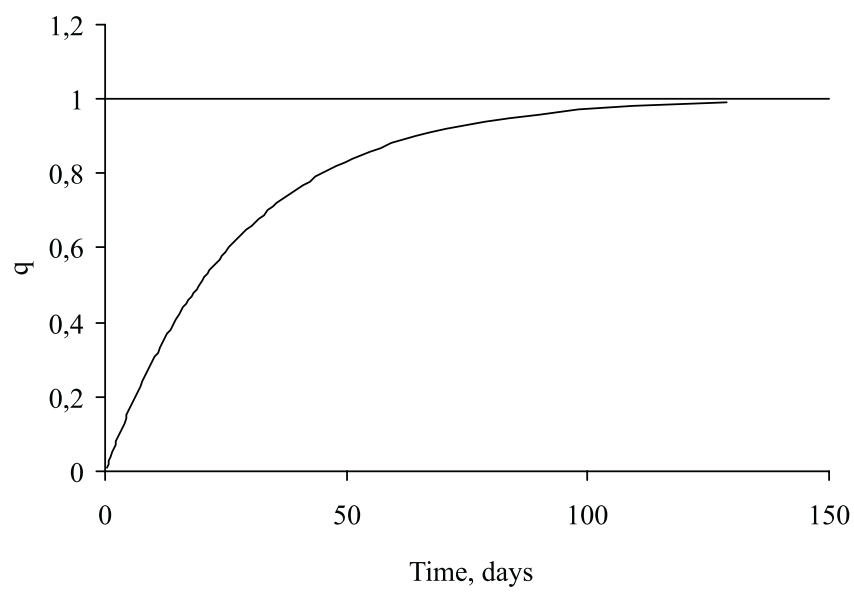

Figura 3 - Metabolism response (in days) to the new feeding level.

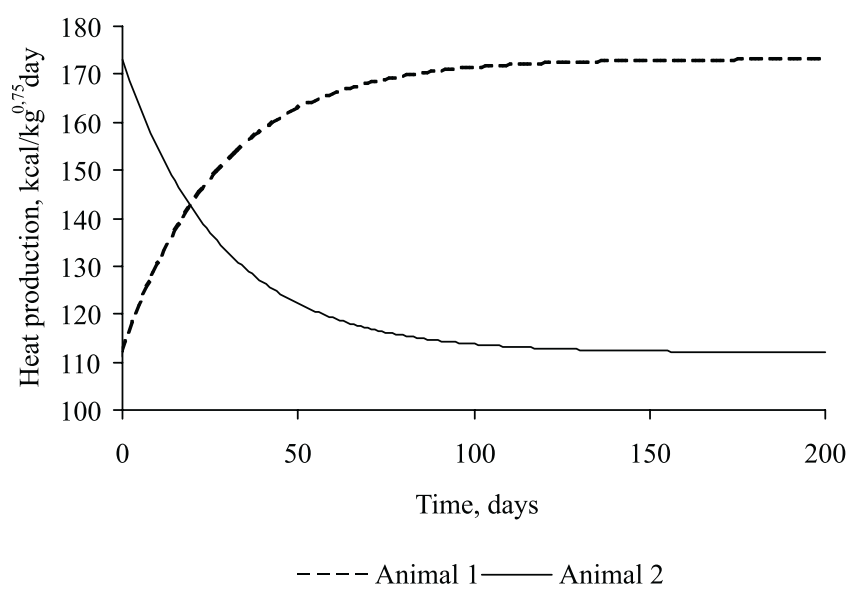

Figure 4 - Heat production in function of time, after changing the nutritional level.

The support metabolism is the increase in energetic expenses caused by the intensification of the processes of digestion, circulation, secretion, maintenance of the concentration gradients, muscular tonus and tissue renewal that occurs on levels above the energetic equilibrium (Milligan \& Summers, 1986). Hence, the less the amount of metabolizable energy used for the maintenance metabolism and support metabolism, the higher the energy availability for body mass gain (energy retention in the body).

The maintenance requirement of a certain genetic group is constant in relation to live weight when the animal is in real energetic equilibrium, that is, when its metabolism is stabilized at an intake level regardless of whether this level is above or below maintenance (Taylor et al., 1981). Therefore, the requirements vary with energy intake, due to the support metabolism. Williams \& Jenkins (2003b) proposed a value of $15 \%$ to each multiple of energy intake above maintenance to account as the increase due the support metabolism. Using this correction, it is possible to determine how much of metabolizable energy consumed was used for body mass gain $\left(\mathrm{MEI}_{\mathrm{g}}\right)$. Consequently, the correction suggested by these authors was applied to the support metabolism, and the $\beta_{0}, \beta_{1}$ and $\beta_{2}$ values were estimated again using the $\mathrm{MEI}_{\mathrm{g}}$ values instead of the MEI (Table 2).

The intercept is not significantly different from zero $(\mathrm{P}<0.05)$, then the discount over metabolizable energy intake included all energetic expenditure for maintenance plus support metabolism. The confidence interval for $\beta_{1}$ was higher than $\beta_{2}$ and proved the greater variability related to the retention efficiency of protein $\left(\mathrm{k}_{\mathrm{p}}\right)$ compared to retention efficiency of fat. 
Table 2 - Point and interval estimates of the parameters obtained after fitting the model that describes the relation between metabolizable energy intake available for gain and the daily increases of body protein and fat

\begin{tabular}{lccc}
\hline Parameter (Mcal/kg ${ }^{0.75}$ day) & Estimate & \multicolumn{2}{c}{ Confidence interval at probability level of 0.95} \\
\cline { 3 - 4 } & & Lower limit & Upper limit \\
\hline$\beta_{0}$ & -0.01 & -0.03 & 0.01 \\
$\beta_{1}$ & 28.92 & 19.13 & 38.71 \\
$\beta_{2}$ & 12.20 & 8.47 & 15.92 \\
\hline
\end{tabular}

There were no signs of tendencies in the residuals in the standard residual analysis (Figure 5), and the proportions of residuals within limits -2 and 2 of standard deviation were higher than 0.95 , indicating good fit to the model adjustment (Draper \& Smith, 1966).

New $\hat{\beta}_{1}$ and $\hat{\beta}_{2}$ estimates made it possible to obtain the values 0.20 for $\mathrm{k}_{\mathrm{p}}$ and 0.78 for $\mathrm{k}_{\mathrm{f}}$, close from those reported by Geay (1984) of 0.20 and 0.75 , for $\mathrm{k}_{\mathrm{p}}$ and $\mathrm{k}_{\mathrm{f}}$, respectively. Using the same method, Williams \& Jenkins (2003b) found $\mathrm{k}_{\mathrm{p}}=0.21$ and $\mathrm{k}_{\mathrm{f}}=0.73$ for data published by Lofgreen $\&$
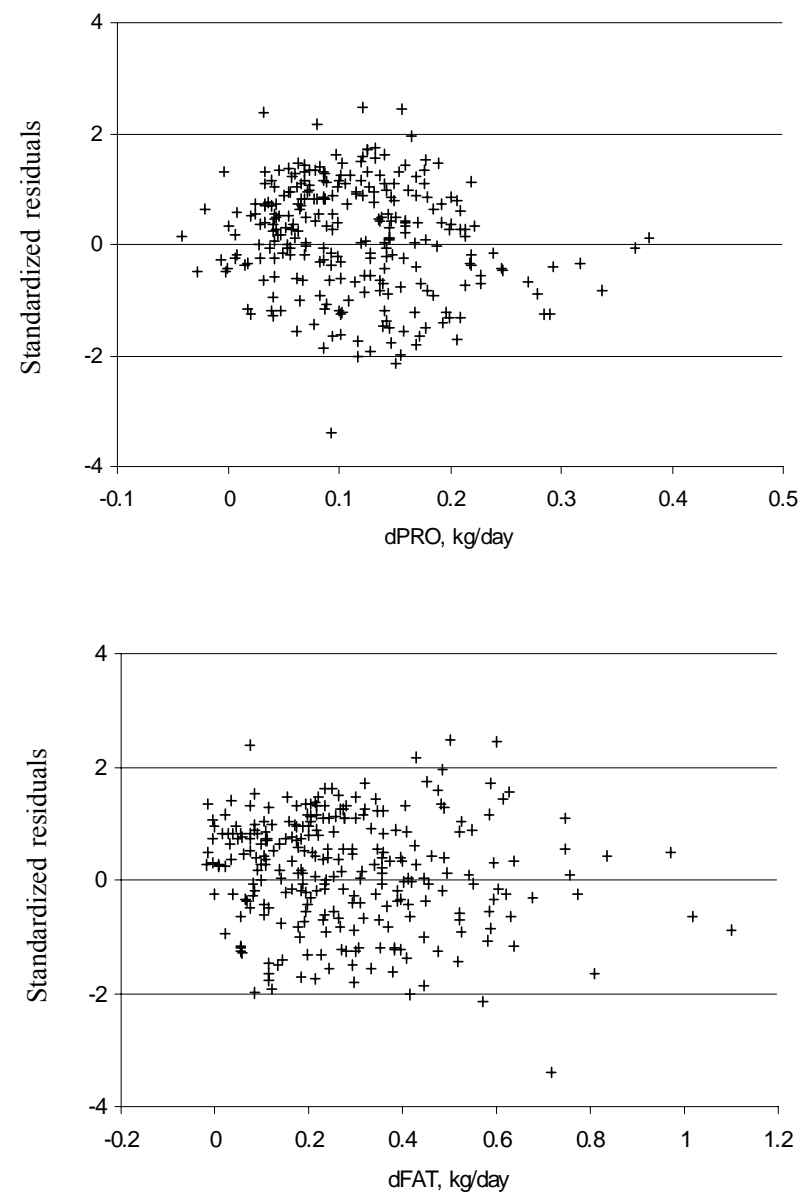

Figure 5 - Estimates of standardized residuals for metabolizable energy intake for body mass gain, $\mathrm{MEI}_{\mathrm{g}}$, related to daily retention of protein (dPRO) and fat (dFAT).
Garrett (1968), that used Bos taurus animals of British breeds. Values found in this study were placed within the confidence interval of the estimates obtained by these authors.

\section{Conclusions}

Energetic efficiency for body retention of protein and fat did not differ between Bos indicus animals and their crossbreds and Bos taurus, because the confidence interval of the estimates found in this study did not exclude the values observed in the literature for Bos taurus animals. The estimate of $15 \%$ for each intake multiple above the maintenance level was adequate to estimate the energetic requirement due to the support metabolism in Bos indicus and its crossbreds.

\section{Literature Cited}

BRODY, S. Bioenergetics and growth with special reference to the efficiency complex in domestic animals. New York: Reinhold Publishing Corporation, 1945. 1023p.

DRAPER, N.R.; SMITH, H. Applied regression analysis. New York: John Wiley \& Sons, 1966. 407p.

FERREIRA, M.A. Desempenho, exigências nutricionais e eficiência da utilização da energia metabolizável para ganho de peso de bovinos $F_{1}$ Simental x Nelore. 1997. 97f. Tese (Doutorado em Zootecnia) - Universidade Federal de Viçosa, Viçosa, MG, 1997.

FREITAS, J.A. Composição corporal e exigências de energia e proteína de bovinos (zebuínos e mestiços) e bubalinos não-castrados, em confinamento. 1995. 75 f. Dissertação (Mestrado em Zootecnia) - Universidade Federal de Viçosa, Viçosa, MG, 1995.

FREITAS, J.A. Exigências nutricionais de energia e proteína e eficiência líquida de utilização da energia metabolizável para bovinos de diferentes grupos genéticos, em confinamento. 2004. 89f. Tese (Doutorado em Zootecnia) Universidade Federal de Viçosa, Viçosa, MG, 2004.

GEAY, Y. Energy and protein utilization in growing cattle. Journal of Animal Science, v. 58, n.3, p.766-777, 1984.

KEELE, J.W.; WILLIAMS, C.B.; BENNETT, G.L. A computer model to predict the effects of level of nutrition on composition of empty body gain in beef cattle: I. theory and development. Journal of Animal Science, v.70, p.841-857, 1992.

LOFGREEN, G.P.; GARRET, W.N. A system for expressing net energy requirements and feed values for growing and finishing beef cattle. Journal of Animal Science, v.27, p.793-806, 1968. 
MILLIGAN, L.P.; SUMMERS, M. The biological basis of maintenance and its relevance to assessing responses to nutrients. Proceedings of the Nutrition Society, v.45, p.185-193, 1986

NATIONAL RESEARCH COUNCIL - NRC. Nutrient requirements of beef cattle. 7.ed. Washington, D.C.: National Academy Press, 1996. 242p.

OWENS, F.N.; DONALD, R.G.; DAVID, S.S. et al. Review of some aspects of growth and development of feedlot cattle. Journal of Animal Science, v.73, p.3152-3172, 1995.

PAULINO, P.V.R. Exigências nutricionais e validação da seção HH para predição da composição corporal de zebuínos. 2002. 158f. Dissertação (Mestrado em Zootecnia) - Universidade Federal de Viçosa, Viçosa, MG, 2002.

SALVADOR, M. Exigências de energia e proteína para engorda de novilhos azebuados. 1980. 70f. Dissertação (Mestrado em Zootecnia) - Universidade Federal de Viçosa, Viçosa, MG, 1980.

STRYER, L. Biochemistry. 4.ed. New York: W.H. Freeman and Company, 1996. 1064p.

TAYLOR, C.S.; TURNER, H.G.; YOUNG, G.B. Genetic control of equilibrium maintenance efficiency in cattle. Animal Production, v.33, p.179-194, 1981 .
TEDESCHI, L. O. Development and evaluation of models for the Cornell Net Carbohydrate and Protein System: Energy Requirements for maintenance and growth. 2001. 395f. Thesis (Doctor of Philosophy) - Cornell University, Ithaca, 2001.

TEIXEIRA, J.C. Exigências de energia e proteína, composição e área corporal e principais cortes da carcaça em seis grupos genéticos de bovídeos. 1984. 110f. Tese (Doutorado em Zootecnia) - Universidade Federal de Viçosa, Viçosa, MG, 1984.

TURNER, H.G.; TAYLOR, C.S. Dynamic factors in models of energy utilization with particular reference to maintenance requirement of cattle. World Review of Nutrition and Diet, v.42, p.135-190, 1983.

WILLIAMS, C.B.; JENKINS, T.G. A dynamic model of metabolizable energy utilization in growing and mature cattle. I. Metabolizable energy utilization for maintenance and support metabolism. Journal of Animal Science, v.81, p.1371-1381, 2003a.

WILLIAMS, C.B.; JENKINS, T.G. A dynamic model of metabolizable energy utilization in growing and mature cattle. III. Model evaluation. Journal of Animal Science, v.81, p.1390-1398, 2003b. 